\title{
Ethnologies
}

\section{A Fatherly Eye: Indian Agents, Government Power, and Aboriginal Resistance in Ontario, 1918-1939. By Robin Jarvis Brownlie. (Toronto: Oxford University Press, Canadian Social History Series, 2003. Pp. $\mathrm{x}+204$, b\&w illustrations. ISBN 0195417844 paper, ISBN 0195418913 cloth)}

\section{Beth Sneyd}

Volume 26, numéro 2, 2004

Québec - Ethnologie du proche

Québec - Ethnology At Home

URI : https://id.erudit.org/iderudit/013759ar

DOI : https://doi.org/10.7202/013759ar

Aller au sommaire du numéro

Éditeur(s)

Association Canadienne d'Ethnologie et de Folklore

ISSN

1481-5974 (imprimé)

1708-0401 (numérique)

Découvrir la revue

Citer ce compte rendu

Sneyd, B. (2004). Compte rendu de [A Fatherly Eye: Indian Agents, Government Power, and Aboriginal Resistance in Ontario, 1918-1939. By Robin Jarvis Brownlie. (Toronto: Oxford University Press, Canadian Social History Series, 2003. Pp. $x+204$, b\&w illustrations. ISBN 0195417844 paper, ISBN 0195418913 cloth)]. Ethnologies, 26(2), 324-327. https://doi.org/10.7202/013759ar d'utilisation que vous pouvez consulter en ligne. 
of songs, as well as a small glimpse into a fascinating web of musical relationships and activities of an isolated sea community. Ultimately, the strength of this book lies on the extent to which the narrative is rooted in the local.

Louise Wrazen

York University

Toronto

\section{Reference}

Hayward, Philip. 2001. Tide Lines: Music, Tourism and Cultural Transition in the Whitsunday Islands (and adjacent coast). Southern Cross University: Music Archive for the Pacific Press.

\section{A Fatherly Eye: Indian Agents, Government Power, and Aboriginal Resistance in Ontario, 1918-1939. By Robin Jarvis Brownlie. (Toronto: Oxford University Press, Canadian Social History Series, 2003. Pp. x+204, b\&w illustrations. ISBN 0195417844 paper, ISBN 0195418913 cloth)}

Canada's aboriginal people have become increasingly visible in the past few decades, filing residential school lawsuits, agitating for a role in constitutional talks or supporting the creation of Nunavut. There is a particular concern with redressing past wrongs. As a result, there has been a growing interest in the history of relations between Aboriginals and the federal government. Authors such as J.R. Miller have contributed to this field with comprehensive and accessible books on this topic. Sadly, such works remain overviews, with little opportunity for addressing specific issues, be it residential schools or hunting rights. It remains for texts like A Fatherly Eye to fill in the gaps. Brownlie's book certainly meets the challenge.

A Fatherly Eye addresses the "Indian agent" system. For nearly a century, the Department of Indian Affairs (DIA) placed agents on the reserves to act on behalf of both Ottawa, and the reserves' residents. Ostensibly, the agents' primary function was to encourage and facilitate aboriginal assimilation into Canadian society and the subsequent transition to Canadian citizenship or enfranchisement. Brownlie argues that as it became increasingly obvious that assimilation was not succeeding as desired, DIA policy gravitated towards an unspoken goal: 
the control of aboriginals. As the primary (and in some cases only) intermediary between the reserves and the DIA on matters such as money, medical expenses, education, and relief, the Indian agent was the key to asserting and maintaining such control $(\mathrm{xv})$, wielding a considerable amount of power over his clients.

A Fatherly Eye presents a case study of two very different individuals who worked as Indian agents in the Georgian Bay area during the interwar period: John Daly, agent for Parry Sound, (from 1922 to 1939) and Robert Lewis, agent for Manitowaning (on Manitoulin Island, from 1915-1939). These men present an interesting study in contrasts, in that "their differences permit an analysis of the varying styles that could be brought to the work, and of the effects of personality differences on policy implementation" (xi). The portraits of the two agents are drawn from their extensive correspondence with the DIA, and are therefore limited to the agents' words. This does not, however, prevent Brownlie from making some effective arguments about the effect of individual personalities on policy implementation and the resulting consequences.

Daly began the job when he was forty-nine, after serving in World War One. Coming from Highland ancestry, he felt certain, albeit limited, sentimental ties with the residents on his reserves. Daly was, Brownlie argues, a firm paternalist (49); in effect, he was the embodiment of Kipling's "white man" - taking care of the people on the reserve was his "burden". He involved himself deeply in reserve affairs, even when he was not wanted. Those who questioned his authority to do so were termed agitators and ingrates in his correspondence with his superiors. Daly's chief sources of irritation were the Band Councils, who constantly expressed their dissatisfaction with the status quo, and called for improvements in conditions. Daly took such criticisms personally, not surprisingly, and would retaliate by defaming his critics to the DIA in their correspondence, making their requests and concerns appear "irrational, petty, foolish, and self-serving" (57). Naturally, such dismissal on Daly's part had an effect on departmental decisions regarding his clients.

Personal conflicts also affected Daly's viewpoint on issues such as education and relief. After Emily Donald, an aboriginal teacher, refused to go to a normal school to upgrade her teaching qualifications, Daly refused to offer such opportunities again (135). When the Depression struck, and many of Daly's opponents were forced to approach him for 
relief, he took a delight in forcing them to participate in road-building projects, to settle old scores (119).

Brownlie is quick to note that Daly was not without good points, personal vendettas aside. He had a belief in pre-existing rights for aboriginals (along the lines of "they were there first"), and acted on behalf of his clients to get extensions on hunting seasons or for giving his clients preference in guiding licenses, arguing that without such opportunities, there would be suffering amongst Aboriginals (90-91). Daly was also generally generous in providing relief for his clients, obtaining clothing for them, or enlisting his agency in road-building projects (110). Nevertheless, his personal approach to his job caused irreparable rifts in his already rocky relationship with his clients.

Robert Lewis, on the other hand, took a low-interventionist approach to his agency. Lewis was a liberal individualist. He involved himself far less in aboriginal affairs, believing his clients to be capable of assuming some responsibility (51). As a result, the band councils in his agency had a greater decision-making power than those in Daly's, although such decisions were equally susceptible to veto. Lewis was not above getting involved when absolutely necessary. In the 1920s, there were inter-band conflicts in his agency on the issue of treaty annuities. This issue was too big for him to ignore, and yet, when he reported it to his superiors, Lewis reduced the importance of the issue to only a small matter between some agitators and some Jesuits. Ultimately, where Daly would have forced a decision, Lewis took a neutral stance, and the issue remained volatile until the 1960s (78). Brownlie suggests several reasons for Lewis' lower level of intervention: apathy, a belief in every man's responsibility to support himself, and even the size of his agency, it being larger and more populous than Daly's (53). There does not appear to be a clear answer.

Lewis supported higher education, requesting new teachers when pressed by his clients, and encouraging children with potential to pursue secondary education (133-134). Still, when it came to everyday matters, unlike Daly, Lewis did not believe in any special consideration for aboriginals based on right. Brownlie argues that Lewis felt that fishing allowance should be based on simple need, recognizing that aboriginals relied more on fishing for food than non-aboriginals did. He never questioned, therefore, the government regulation of hunting and fishing industries as Daly occasionally did (114). Lewis took a similar hard- 
line approach on the issue of assistance. A firm believer in the maxim of "every man for himself", Lewis was very strict about issuing relief to those who were able-bodied and old enough to work for themselves. This policy backfired during the Depression when it became clear that there was simply no work for his clients (54-55). Even then, Lewis did not enlist his agency in road-building projects as Daly had done, and was very frugal in how much financial relief he provided (112-114).

A Fatherly Eye would be of interest to any scholar concerned with policy, aboriginal issues, or Canada's social history. It paints an effective portrait of two very different individuals, with some interesting and valuable insights into the mechanics of the Indian agent system. Given the amount of control Indian agents had (or chose to have), it is not surprising that the system had a destructive effect on Canada's aboriginal peoples. The amount of power given to the agents was considerable, and the result was a series of subjective decisions. While neither Daly nor Lewis was granted carte blanche by the DIA, they were given a great deal of discretionary power to involve themselves as much or as little as they desired.

It is clear that Brownlie sees little or no merit in the Indian agent system, the exception being that aboriginals who lived on reserves were perhaps marginally better off during the Depression than those who did not. This assessment is a fair one. The Indian agent system was antiquated and highly patronizing, and yet its values were a reflection of its time. A Fatherly Eye also highlights the power an individual can have on policy implementation. One only needs to read about Daly and Lewis' decisions and their results to see this.

Beth Sneyd Royal Military College of Canada Kingston

\section{Reference}

J. R. Miller. 2001. Skyscraper Hide the Heavens: A History of IndianWhite Relations in Canada. Toronto: University of Toronto Press, 3rd ed. 